\title{
TRADE UNION PRACTICES IN AN INDIAN BATTERY INDUSTRY: A STUDY
}

\author{
Panthula Sree Sai Pavan ${ }^{1}$ \\ ${ }^{1}$ Research Scholar, Dept. of Management, Dravidian University, Kuppam, A.P. \\ Prof.G.L.Narayanappa ${ }^{2}$ \\ ${ }^{1}$ Dean, School of Commerce and Management, Dravidian University, Kuppam, A.P.
}

Article DOI: https://doi.org/10.36713/epra4739

\section{STATEMENT OF THE PROBLEM}

$\mathrm{ABC}$ Batteries India Limited is one of the world class batteries manufacturing company established in the year 1985 and competing the global standards and competition in producing and marketing of batteries. It is the firm opinion of the 'ABC' Batteries Company that the standardization of quality of life by way of establishing the institution can extend evergreen accessibility to enhanced prospects and advantages to the mankind. By introducing the advanced engineering technology and scientific research, the ' $\mathrm{ABC}$ ' Batteries Company has entered into MOUs with global companies and making partnership ventures with world class leaders for want of transfer and sharing of technology and proficiency.

After establishing the industry as a private one subsequently in the year 1990 the industry was converted as public limited industry. The $\mathrm{ABC}$ Batteries Company has entered into MOU with an international industry of USA on partnership basis with a partnership percentage of 22 .

\section{IMPORTANCE OF TRADE UNIONISM IN INDIAN BATTERY INDUSTRY}

In the recent times, there has been a regeneration of importance in the relationship between the employees and the unions. Hence, the swing to this drastic modernisations is that, the trade unions are playing vital role in central deliberations about the repercussions of contraption. Hence, the need of the hour is that the nature of relationship which the union should maintain with the management and the organization should implement the same for the benefit of their employees/workers. Securing highest salaries/wages for the employees/workers and safeguarding of the job security and extent of protection for the employees/workers should be the vital aspects of motto of the trade unionism. Hence, it is stated that the trade unions should work for the increasing the productivity only when the hob-nob relations are prevailed between managements and the unions ${ }^{(1)}$.

The degree of unionism will play an enormous role in achieving its production targets. The battery industry has no exception for this. Hence, it is inevitable to seek the concern and co-operation of unions for achieving the production targets. The full pledged co-operation and efforts of the employees/workers can be expected only when the union maintains good relations with the management alone. Otherwise the organisations can not think of achieving production targets ${ }^{(2)}$.

It is obviously apparent that the concept of trade unionism is the vital parameter in the organisations to extract the maximum productivity from the employees. Recently, it is realized from the preceding decade that the sufficient strength of the union scientifically accomplishing the inclination of employees towards their job responsibility and eventually about the rate of employee turnover that would be reduced in the organisations to the most extent. Even though, the number of efforts offered by the organisations for the employees, certain interruptions have been observed during the course of productivity. In order to identify the specific reasons for the efforts of the union to wipe out such interruptions that this study has been takenup ${ }^{(3)}$. 


\section{EPRA International Journal of Research and Development (IJRD)}

It is realized that the various efforts extended by the unions will have immediate influence towards the productivity, psychological capability, physical health, foresight, attitude and all round adoptability of the employees for the circumstances for achieving larger productivity. Further the prime purpose of the trade unionism is to augment the lives and careers of employees to extend them happiness and encouragement.

Further, in the era of global competition in the market for battery products, the success of 'ABC' batteries compnay very much depends on the performance of union which is required for the organization to grab its share in the market towards the accomplishment of pre-determined goals. As per the philosophy of industrial relations the unions are the prime source which should be given at most priority to maximize the return on the capital to fulfill the business targets. The 'ABC' batteries company should put maximum efforts for the strengthening unions of their organisation and should extend all the facilities to the employees without single exception.

\section{REVIEW OF LITERATURE}

Lawrence Egulu, (2004), in his study the author emphasized on the participation of trade union in the PRSP process. Through this research it is noticed that there is a huge emergency of upgrading the industrial skill sets and craftsmanship. Skills and training and development procedures will improve their standards, high quality, accessibility and relevance. It was noticed that the trade unions in MSMSE are much impacting on the economic growth and in generating of new employment opportunities. Creation of healthy atmosphere and harmonious relations depend upon the trade unions $^{(4)}$.

NtwalaMwilima,(2008), the author underlined in this study that there is significant need of decent and sustainable jobs, which alleviate poverty. It is observed through this study that the trade union plays crucial role in job creation. Trade unions shows their impact on the macro-economic and social policies which plays, catalyst role in providing skill development training and job creation for main workers and extends development assistance. Trade unions involving and creating the direct and indirect jobs. In this study the author concluded that the trade unions play pivotal role in eradicating the unemployment in South Africa (5).

Verena Schmidt, Maarten Keuneand Kevin Skerrett (ILO),(2009), have analysed the impact of the welfare practices in business environment and the consequences on the productivity of the organisation. Trade unions removed the hindrances of individual employee unions associations problems. Trade unions have exhibiting the wide range of impact on the collective bargaining process. The collective bargaining plays utmost role in providing rules and measures for adequate earnings, judicial protection and social security. In the era of non-standard employment alliance, the rules and regulations designed by the parties involved in collective bargaining are not valid. Despite of that the pricing and allocation depends upon the market forces ${ }^{(6)}$.

PiyaliGhosh, ShefaliNandan, Ashish Gupta,(2009), In this research paper the authors stressed on the trade unions and stated that they involves actively in building sound working environment of NTPC as a part from maintaining viable industrial relations, Moreover, it is observed in this study that the welfare approach of the trade union is inspirable. It was evidenced in this study that membership in the trade unions are declining drastically over the period of time. Therefore, the researchers implicated that the active involvement of trade unions will attract more members into unions and increase welfare practices also to augment the union's membership ${ }^{(7)}$.

Josephine SeapeiMoeti-lysson, (2011), In this study the author emphasised on the concept that, whether the Botswana teaches union participated in labour relations or not. It implicates that there is a significant connection between the members and the trade unions. Botswana teaches union plays significant role in resolving the problems. Trade unionism as an ideology favours membership, since it strengthens the social recognition of the members and reduces the psychic of punishing non-members. Internal market affects the trade unions negatively due to control of unions, whereas unions stimulates the members to socialise their contacts among the members, which leads to less working hours and allows employees to meet during the leisure ${ }^{(8)}$.

Erik Bengtsson(2013), in this research paper the author empahsied on the income districpation between labour and capital market of Swdesh trade unions. It is underlined that the outsourcing agencies are using veto powers to invove in the trade unions. Author implicated the ambiguity of Swedish trade unions in usage of veto powers. It categorises that the consultation of union and the veto powers are two separate entities and the union upholds the diversity of labour market in developed economies ${ }^{(9)}$.

\section{SCOPE OF THE STUDY}

The scope of this study is confined to the trade union practices of 'ABC' battery company only. The outcomes of this study cannot be comparable to any other similar industry or organisation. 


\section{EPRA International Journal of Research and Development (IJRD)

\section{OBJECTIVES OF THE STUDY}

The distinct objectives of the study are:

i. To investigate the breathing of practices of trade union in $\mathrm{ABC}$ batteries industry;

ii. To assess the level of satisfaction/dissatisfaction of employees/workers towards the breathing practices of trade union in 'ABC' Batteries Company;

iii. To scrutanise the reasons for the dissatisfaction of employee/worker respondents towards the breathing practices of trade union in 'ABC' Batteries Company; and

iv. To furnish the acceptable counter measures to flatten the dissatisfaction prevailed among the employees/workers towards the breathing practices of trade union in 'ABC' Batteries Company.

\section{RESEARCH METHODOLOGY}

The methodology consists of data collection from primary as well as secondary sources. Through the survey method the first hand information was collected from 50 sample respondents from the study unit.

\section{Sample design and size}

A purposive-cum-convenient sampling technique was followed and 50 respondents were chosen as sample respondents from the study unit.

\section{ANALYSIS OF THE DATA}

The information collected from the respondents was processed and tabulated scientifically and several statistical tools like (i) Independent sample t-test; (ii) Weighted mean scores; (iii) 'ANOVA' are calculated at appropriate levels and the inferences were drawn.

\section{The Limitations}

1. The study is confined to only one battery industry located in India;

2. The size of the sample is 50 only where the number is meagre.

\section{RESEARCH FINDINGS}

1. The advancement of trade unionism from the implementation of employee welfare function towards a character forced by voice and delegation of employees appears to have taken freedom against the backdrop of the representation of employees/workers seems that there is a periodical and frequent interference of the unions which is resulting negatively $(36.00 \%)$.
2. The high rate of enrolment of membership in unions with exorbitant contributions is not strengthening the bargaining power of unions and not at all deriving any successful outcomes. Further, the bargaining power of the unions is also unchanged $(34.00 \%)$.

3. The unions are not able to properly collaborate with the management and also not able to command the managements for impersonal distribution of hierarchy $(28.00 \%)$.

4. The present unions are putting their maximum efforts for enrolment more members into their unions to strengthen their members vote bank for achieving success in forthcoming union elections and to support certain political parties $(26.00 \%)$.

5. The way of discharging the responsibilities of unions towards the implementation of employee welfare programmes is not admirable and significant. The union is discharging its responsibility only as an eye wash exercise and not at all concentrating on basic issues of employee welfare $(22.00 \%)$.

\section{SUGGESTIONS}

1. The multiplicity and mushroom birth of unions should be regulated. The union members must elect a leader for their unions such a person with high integrity, loyalty, moral values and ethics who will not attracted to the temptations of the managements. Further, the proposed union leader must be a highly educated person who is having certain commitment towards the welfare of the fellow workers. So that the employee welfare programmes would automatically be implemented and such a honest and highly educated union leader will concentrate full time on solving the problems of individual workers.

2. For want of the implementation of the employee welfare programmes towards a character forced by the voice and delegation of employees, the unions should take the consensus of each and every individual employee. So that the freedom of the individual employees can be safeguarded and the reasonable attention can be paid to the representations of the employees with regard to the implementation of employee welfare programmes. Further, the periodical interface with the workers by the management should be resulted in effective implementation of the long pending benefits of the employees without giving any scope to negative impact. 


\section{EPRA International Journal of Research and Development (IJRD)

3. Further, the enrolment rate of members into the unions should be minimized and the contributions to be collected from the members should also be enormously reduced. Collection of exorbitant contributions would result in landing the poor workers into debts with higher rates of interest.

4. The unions and union leaders should have cooperative attitude with the management towards positive things only which can enhance the welfare and wellbeing of both employees and employers too. Then only the unions would be able to command the managements for impersonal distribution of hierarchy.

5. The unions should play catalytic role between the employees/workers and the managements. Innumerable number of illiterate workers should not be enrolled as members in to the unions forcibly for want of their membership contributions. When, the workers are really interested in enrolling the unions, then only they should be admitted.

\section{REFERENCES}

1. Josephine Seapel Moeti-Lysson: "Effectiveness of Trade Unions in promoting employee relations in organisation", Research gate, Jan-2011, pp.56-57

2. Purshothaman.G, Manjual purshothaman and Krishanmurthy.K: "A study on employee welfare measures in Neycer India Ltd", Journal of Human Resource Management and Development, Vol.4, June 2014, p.23.

3. Subhasish Chaterji, Medha Wadhva and Dhrashana Patel: "A study on employee welfare and its impact on their performance at private hospitals and its research centre-cross sectional descriptive study", IJRAR, 2018, Vol.5, issue.12, p.504.

4. Lawrence Egulu, 2004, Trade Union Participation in the PRSP Process, Social Protection Unit Human Development Network The World Bank, No. 0417.

5. NtwalaMwilima, The role of trade unions in job creation: a case study of the Job Creation Trust, The University of the Witwatersand, December 2008.

6. Verena Schmidt (ILO) Maarten Keune (University of Amsterdam) Kevin Skerrett (ILO),Global capital strategies and trade union responses: Collective bargaining and transnational trade union cooperation, International Journal of Labour Research Geneva, International Labour Office, 2009 ISBN 978-92-2-122725-0 ISSN 2076-9806, Vol. 1 Issue 2.
7. PiyaliGhosh, ShefaliNandan, Ashish Gupta, the changing roles of trade unions in india: a case study of national thermal power corporation (ntpc), unchahar, Asian Academy of Management Journal, Vol. 14, No. 1, 37-57, January 2009

8. Josephine SeapeiMoeti-lysson, Effectiveness of trade unions in promoting employee relations in organisations. Department of Management, University of Botswana, Private Bag 0022, Gaborone .Botswana, Global J. Of Arts \& Mgmt., 2011: 1 (4)

9. Erik Bengtsson, Essays on trade unions and functional income distribution, ISBN 978-9186217-08-2 Published by the Unit for Economic History, Department of Economy and Society, School of Business, Economics and Law, University of Gothenburg Printed by Ineko, Göteborg 2013 